\title{
Truthmaking for Modal Skeptics
}

\author{
Jamin Asay \\ Lingnan University \\ Forthcoming in Thought
}

\begin{abstract}
Standard truthmaker theory has generally assumed a realist account of de re modality and essences. But there are reasons to be skeptical about such a view, and for considering anti-realist alternatives. Can truthmaker theory survive in the face of such skepticism? I argue that it can, but that only certain anti-realist perspectives on de re modality are acceptable for truthmaker theory. In particular, either a quasi-realist or conventionalist account of de re modality is needed to provide the best account of essential and accidental features that can be put to work in truthmaker theory. An important consequence of this approach is that it offers an account of truthmaking that is consistent with a nominalist perspective on properties, and yet fully respects the ontological ambitions driving truthmaker theory.
\end{abstract}

\section{Truthmaker Theory and $D e$ Re Modality}

Truthmaker theory, as standardly practiced, generally presupposes a realist understanding of de re modality. De re modality, as I shall be discussing it, is the area of metaphysics concerned with the essences of objects, essential and accidental properties, necessary and contingent predications, and other similar matters. To be a realist about de re modality is to accept that there are facts about essences, essential properties, and the like, and that the truth of these facts is a mind-independent, objective matter. ${ }^{1}$ While truthmaker theory has operated on the assumption of realism about de re modality, it can be set free from this constraint. In this paper, I first explain how realism about de re modality has been presupposed by standard truthmaker theory, and then

\footnotetext{
${ }^{1}$ By 'fact' I mean nothing more than 'true truth bearer'. I shall use propositions as my preferred truth bearers, though nothing crucial hangs on this decision. The expression ' $\langle p\rangle$ ' is shorthand for 'the proposition that $p$ '.
} 
show how truthmaker theory can survive without it. An important consequence of this different approach is that it offers an argument in defense of a nominalist-friendly theory of truthmaking. The ontological virtues of the perspective I am offering are thus twofold: it eschews any ontological commitments required by realism about de re modality, and avoids any commitments to contentious metaphysical posits such as tropes and states of affairs.

To see how truthmaker theory is committed to realism about de re modality, we need to explore why the truthmaking relation obtains where it does. When some object $\mathrm{X}$ is a truthmaker for some proposition $\langle p\rangle$, that is because X's existence somehow accounts for the truth of $\langle p\rangle$. Exactly what this "accounting" comes to is controversial, ${ }^{2}$ and the details need not concern us here. What is generally accepted is that the accounting in question is a modal matter, in that it involves claims about what is possible and necessary. Notably, most truthmaker theorists accept the necessitation thesis, namely, that $\mathrm{X}$ is a truthmaker for $\langle p\rangle$ only if it's metaphysically necessary that if $\mathrm{X}$ exists, then $\langle p\rangle$ is true. ${ }^{3}$ Were it possible for $\mathrm{X}$ to exist, and yet $\langle p\rangle$ be false, then $\mathrm{X}$ does not yet account for the truth of $\langle p\rangle$.

To employ truthmaker theory, then, one must engage in some modal thinking. Whether or not an object is a truthmaker for some proposition depends upon the various ways that the object does or doesn't have to be. For example, consider the following pair of propositions:

$$
\begin{aligned}
& <\text { Socrates is human }> \\
& <\text { Socrates is a philosopher }>\text {. }
\end{aligned}
$$

To determine what, if anything, makes these propositions true, we need to consider what it is that, at the least, necessitates their truth. On the standard view, Socrates himself is a truthmaker for (1) because it's necessary that if Socrates exists, then he's human. But Socrates might have been a sophist. So it's not necessary that if Socrates exists, then he is a philosopher, and so Socrates is not a truthmaker for (2). As a result, truthmaker theorists posit the existence of other entities that do necessitate contingent predications, such as states of affairs (Armstrong 2004) or tropes (Lowe 2007).

Truthmakers theorists are thus committed to the cogency and truth of claims to the effect that certain propositions would or wouldn't be true had certain objects existed or not. My claim is that standard truthmaker theory has been operating - if sometimes only implicitly_on

\footnotetext{
2 See, e.g., Restall 1996, Armstrong 2004, Merricks 2007, and Sanson and Caplan 2010.

${ }^{3}$ Merricks refers to necessitation as "truthmaker orthodoxy" (2007: 5). Cameron (2008c: 107), Schaffer (2008: 10), and Goff (2010: 45) concur.
} 
the assumption that a realist conception of de re modality is what underwrites and legitimizes these claims. In particular, it is the essence that an object has that explains which truths it does or doesn't necessitate. Because Socrates is essentially human, he is a truthmaker for (1). Because Socrates is accidentally a philosopher, he is not a truthmaker for (2).

Positing essences is not the only way of accounting for why Socrates's existence necessitates the truth of (1) but not (2), but it is the method that truthmaker theorists are most plausibly using. ${ }^{4}$ Notice that claiming that essences account for necessitation is not to hold that essences can be analyzed in terms of necessitation (such that one would be denying the kind of view put forth by Fine 1994). Instead, essences are taken as more fundamental, as what explain necessitation. If one takes necessitation claims to be more fundamental than claims about essences, one bears the burden of offering some other account of why it's necessary that if Socrates exists, he's human, but not necessary that if he exists, he's a philosopher. That's a burden that truthmaker theorists have not taken up. Alternatively, one can take necessitation claims to be brute, but that too falls outside the spirit of truthmaker theory, which resists accepting that there are truths that cannot be accounted for. The best explanation for why these alternative avenues have not been explored is that truthmaker theory has been assuming (sometimes tacitly) a realist perspective on essences.

That truthmaker theory presupposes the legitimacy of de re modality has been observed before (e.g., Fox 1987: 189 and Merricks 2007: 14). Discussions and formulations of truthmaker theory frequently employ the language of essences and essential properties, ${ }^{5}$ sometimes even collapsing the distinction between, say, contingent and inessential predications (e.g., Beebee and Dodd 2005). E. J. Lowe's specific account of truthmaking is defined in terms of essences (2007). In general, truthmaker theorists freely talk about what properties are or are not essential to objects, and about which predications are essential or accidental. ${ }^{6}$ Such claims are never challenged as being metaphysically controversial, unlike many other theses familiar to truthmaker theory.

\footnotetext{
${ }^{4}$ Note that essences account for necessitation only on the assumption that if some object is essentially a certain way, then it's necessary that if that object exists at all, it is that way. Some have disputed this conception of essence (e.g., Salmon 2005), and so such views are of no help to truthmaker theory here.

5 See, e.g., Lewis 2001, Dodd 2002, Parsons 2005, Rodriguez-Pereyra 2005 and 2006, and Cameron 2008a and 2008b.

${ }^{6}$ Note that I am using 'property' in a non-committal way, and so the word need not designate sparse properties in the Armstrong/Lewis sense, nor anything that a nominalist could not countenance. One could be a nominalist about properties and still be a realist about de re modality; such a view would advance the objectivity of essentialist predications without recourse to property-like entities.
} 
Further evidence that truthmaker theorists have happily adopted essences is that doing so provides them the resources for answering other questions important to truthmaker theory. For example, it's generally accepted that not every object is a truthmaker for every necessary truth, although every object necessitates every necessary truth. As a result, many have argued that truthmaking is a hyperintensional relation (e.g., Schaffer 2008). If truthmaking is accounted for in terms of hyperintensional accounts of essences—as Lowe's is, for example-then this problem is dodged.

There are a number of reasons why I detect a realist stance behind the prolific use of essentialist language in truthmaker theory. Some are sociological, others dialectical. Truthmaker theory has thrived in a professional environment that is friendly toward realist stances on metaphysical issues. Many find support for realist perspectives on modality in the writings of Kripke (1972) and Putnam (1975), and Quinean skepticism about modality $(1961,1966)$ is no longer a dominant view. Furthermore, contemporary discussions of anti-realist perspectives on modality (e.g., Blackburn 1986 and Sidelle 1989) are few and far between, and have so far not intersected with the existing truthmaker literature. If truthmaker theorists were not assuming a straightforwardly realist perspective to underwrite their essentialist language, we would expect some recognition of that fact, and acknowledgment that some kind of non-realist account needs to be given for the widespread use of de re modal notions found in the very formulations of their theories. But that is not what one observes in the truthmaking literature. Given that truthmaker theorists are generally open and friendly to realist metaphysical perspectives, ${ }^{7}$ it comes as no surprise that they would take realism about essences and de re modality seriously.

In summation, truthmaker theory requires some form of commitment to de re modality in order to account for its claims as to when the truthmaking relation does or doesn't obtain. Standard practice in truthmaker theory is to assume some form of essentialism that legitimizes such claims, and accept a realist, unproblematic attitude toward them. Objects are essentially some ways (due, perhaps, to their origins, or whatever else it is that accounts for their essences), but only accidentally other ways. Whether some given feature of an object is essential or merely accidental to it is a mind-independent matter, not dependent upon our ways of speaking or thinking about the object.

\footnotetext{
${ }^{7}$ But by no means are they required to be so, as I argue in my 2012.
} 


\section{Truthmaking and Modal Skepticism}

Though realism about de re modality and essences has so far been presupposed by the truthmaking literature, it need not be. Truthmaker theory can survive without it; plus, as I argue in the next section, the resources available to anti-realists (or "skeptics") about de re modality provide an argument for a nominalistically-acceptable and ontologically lean approach to truthmaking. ${ }^{8}$ Furthermore, modal skeptics can avoid the ontological and theoretical costs that accompany realism. They need not posit the existence of Aristotelian essences, nor accept facts about essences or necessitation as brute. It is not my present intent to argue against realism about de re modality, nor argue for modal skepticism (see instead Blackburn 1986 and Sidelle 1989). Rather, my aim is to explain what sort of modal skepticism is suitable for truthmaker theory, and showcase the ontological gifts it brings along with it.

As seen above, the notion of truthmaking is indispensably modal. Whether $\mathrm{X}$ is a truthmaker for $\langle p\rangle$ depends upon whether or not it's necessary that X's existence accompanies $<p>$ 's truth. The most straightforward way of accounting for the relevant modal facts here is to accept a realist account of essences. Entities like Socrates have certain essences, and these essences explain which of Socrates's features are essential to him, and which accidental. The realist maintains that such modal facts about Socrates are an objective, mind-independent matter. But truthmaker theory can dispense with this realist attitude toward these modal facts; nothing about the objectivity of such facts is crucial for the truthmaking enterprise. These modal facts, however, cannot be dispensed with altogether. It still must be true that Socrates's existence guarantees, with metaphysical necessity, the truth of $<$ Socrates is human $>$, if he is to be its truthmaker. Thus, the kind of modal skepticism available to truthmaker theory must be of a particular kind.

The modal skeptic is one who doubts the full objectivity or even existence of de re modal facts. For present purposes, let us focus on claims to the effect that some feature is accidental or essential to an object. Two forms of modal skepticism are unavailable to truthmaker theorists. First, a Quinean perspective on de re modality would take on the attitude that there's "no fact of the matter" regarding which features are essential or accidental to objects. Quine's preferred regimented theory of the world would just leave out modal notions altogether. As a result, Quinean wholesale skepticism about modality is of no use to truthmaker theorists, whose key notion is inextricably modal.

\footnotetext{
8 I use 'skepticism' interchangeably with 'anti-realism', both of which are synonymous with Sidelle's (1989) 'conventionalism'.
} 
Error-theoretic approaches to modality (cf. Mackie 1977 and Field 1980) would also appear to be incompatible with truthmaker theory, and for similar reasons. The error theorist also rejects the truth of (positive) modal claims such as $<$ Socrates is essentially human $>$ because there is no realm of independent modal reality (such as the existence of Aristotelian essences) to make them true. But whereas the Quinean claims no fact of the matter, the error theorist detects falsity. Yet if claims about essences and accidents are systematically false, it's unclear how they can guide truthmaker theory. If it's false that Socrates is essentially human, we cannot explain why Socrates makes true $<$ Socrates is human $>$.'

What truthmaker theory requires from de re modality is that there be true claims about what is or is not essential or accidental, and neither the Quinean nor the error theorist accounts for such facts. The kind of modal skepticism appropriate for truthmaker theory must grant that there are facts about essences and accidents, although these modal features are to be accounted for in some kind of mind-dependent fashion. Two existing positions are capable of such a chore. First is Sidelle's conventionalism, according to which essential predications arise from our linguistic conventions (1989). The reason why water is essentially $\mathrm{H}_{2} \mathrm{O}$ is that it is a matter of linguistic convention that 'water' refers to whatever substance it is that shares the same deep explanatory features as the stuff that flows from our faucets and fills our oceans. To talk about some other substance (such as XYZ) is not to talk about water, since what we mean by 'water' is inextricably tied up with its actual chemical structure. The second account is Blackburn's projectivist quasi-realism about modality (1986). For the quasi-realist, judgments about essential and accidental features can be perfectly truth apt (and true), but their fundamental role in our thought is to express our commitments and attitudes about how we think about objects rather than track some independent realm of modal fact. Now, it is beyond the scope of this paper to defend the individual merits of these anti-realist alternatives. I mention them primarily to demonstrate that there are anti-realist approaches to de re modality that can play a role in truthmaker theory, given that they uphold the legitimacy of essential and accidental predications. The tenability of such a view is necessary for any modal skeptic who seeks to embrace truthmaker theory.

\footnotetext{
${ }^{9} \mathrm{I}$ admit that it may be possible for an error theorist to attempt to reclaim modal assertions while still maintaining that they are strictly speaking false, and in a way that could fund serious truthmaker theory. What remains to be seen is what motivation might lie behind packaging such a perspective on de re modality with truthmaker theory. My thanks go to a referee for suggesting this possibility.
} 


\section{Truthmaking, Nominalism, and Modal Skepticism}

I've argued so far that, pending the viability of some factualist, non-error theoretic anti-realist perspective on de re modality, truthmaker theory can survive without realism about essences. But this result is not just an interesting fact about some occupiable corner of logical space. There are specific ontological virtues that arise from pairing truthmaking with modal skepticism, ones that go beyond the package's ability to dispense with realist essences (which is itself no small gain over standard truthmaker theory). In particular, I argue that modal skeptics can defend a robustly nominalist account of truthmaker theory that avoids the ontological costs (via, say, Armstrong's states of affairs or Lowe's tropes) that many truthmaker theorists face.

To see how the argument goes, consider first that objects like Socrates are typically ontologically accepted by all parties to the debate-nominalists and realists (about universals or tropes) alike. What's controversial is whether or not further entities like tropes or states of affairs exist. For those who accept that predications need truthmakers, the decision to add a state of affairs or trope to one's ontology comes down to the question of whether or not the predication is accidental or essential; only in the former case does one's ontology grow beyond what's nominalistically acceptable. But from the perspective of modal skepticism, this kind of decision is irrational. Whether a feature is held accidentally or essentially amounts to certain minddependent facts about how we are regarding the objects in question. So questions about what sorts of mind-independent entities (like states of affairs or tropes) exist shouldn't themselves turn on what our particular practices or conventions are. Put another way, on the standard view, states of affairs or tropes are posited in order to come to terms with the metaphysical grounds for accidental predications, which pose unique metaphysical challenges that don't arise for essential predications. But according to the modal skeptic, there is no genuine metaphysical (i.e., mind-independent) difference between essential and accidental predications, and so whatever differences there are cannot sustain the distinctly metaphysical inquiry into whether entities such as states of affairs or tropes exist.

Hence, the modal skeptic should argue for parity between truthmakers for essential and accidental predications: accidental predications require states of affairs or tropes if and only if essential predications do. So far, parity doesn't tell in favor of nominalism or realism. Either we need to adopt more states of affairs or tropes than previously thought, or we can get by without any. To break the tie, we need to consider what other resources the modal skeptic has available. For the skeptic (of the kind I am recommending), when we deploy 'Socrates' we are making use of a particular "modal profile" that assigns essentiality or accidentality to Socrates's features. 
What it is to talk about Socrates is to talk about something with a certain modal profile; in this case, Socrates is essentially human, and accidentally a philosopher (among other things).

Now imagine an object just like Socrates, but with a slightly different modal profile. In addition to the object's origins, say, being essential to it, so too is its philosophizing. Call this object 'Philocrates'. Philocrates, I maintain, has just as much "right" to exist as does philosophizing Socrates. Both have the same non-modal features, and are located in the same spatiotemporal region. Any reason to think one exists is reason to think the other exists. From the perspective of modal skepticism that maintains that modal profiles are not, like Aristotelian essences, further objective existents in the world, Socrates and Philocrates both exist, alongside countless others; it's just that (until now) we have conventions enabling us to refer to only one of them. On this view, there exists a plenitude of objects-one corresponding to each and every modal profile of each and every object. ${ }^{10}$

Plenitude is by no means a necessary addition to the modal skeptic's platform. (Sidelle (2009), for instance, does not endorse it.) But it is a natural complement. Once we accept that modal profiles are fundamentally decided upon rather than discovered, we can appreciate that we don't have to choose between the existence of Socrates and Philocrates; we just have to choose which one we want to focus our attention on. By contrast, a non-skeptic is more likely to think that there are "modal joints" in nature, and that the line between Socrates's essential and accidental features is marked by one. If there are no such joints, then it begins to seem arbitrary to think that one modal profile (Socrates's) is instantiated whereas another (Philocrates's) is not. Similarly, once one begins to countenance the existence of some mereological sums, it's hard to see why one shouldn't countenance all mereological sums, on pain of anthropocentrism. Hence, this kind of modal plenitude about objects is just as amenable to modal anti-realism of the kind I am defending as, say, mereological universalism (i.e., that every mereological sum of existing objects itself exists) is to Humean metaphysics.

With this plenitude of (nominalistically acceptable) individuals on board, we can provide truthmakers for contingent predications. What makes <Socrates is a philosopher $>$ true is Philocrates. For it's necessary that if Philocrates exists, then Socrates is a philosopher. After all, Philocrates is essentially a philosopher, and so if he exists at all, so too will Socrates be a

\footnotetext{
${ }^{10}$ Note that the basic idea here is shared by those who argue that the best solution to the statue and the clay puzzle is that both exist, and are located in the same spatiotemporal region. See also Hawthorne 2006, and Bennett 2004, which labels the view 'bazillion-thingism'. Bennett sees the view as a competitor with conventionalism, and may be understanding the view to not be a form of modal skepticism; she takes it to be a kind of primitivism about de re modality. There is much more discussion to be had concerning the relationships between modal skepticism in general, the conventionalist tradition in particular, and plenitude, which unfortunately I cannot undertake here.
} 
philosopher. Likewise for other contingent predications. If $S$ is accidentally $P$, then what makes $<S$ is $P>$ true is some individual $S^{*}$ that is non-modally identical to $S$ but essentially $P{ }^{11}$ An immediate advantage of my view is that, while it does posit the existence of entities like Philocrates and others, these entities are of the same familiar kind as Socrates, which cannot be said for tropes and states of affairs. In other words, the quantitative costs accompanying plenitude are mitigated by the qualitative advantages that it yields. Socrates and Philocrates differ only in their modal features, just like the (clay-constituted) statue and the (statue-shaped) lump clay. Tropes and states of affairs, by contrast, are contentious metaphysical posits different in numerous ways from nominalistically-acceptable individuals. Furthermore, since the existence of a philosophizing Socrates necessitates the existence of Philocrates, one might hold that the existence of the latter is an "ontological free lunch" accompanying the existence of the former. If so, there may be no genuine quantitative costs involved, either.

Those familiar with David Lewis's final views on truthmaking will no doubt see a strong resemblance between my proposal and his. For Lewis (2003), the truthmaker for $<$ Socrates is a philosopher $>$ is Socrates himself conceived under a particular counterpart relation: Socrates qua philosopher. Socrates qua philosopher is essentially a philosopher because all of Socrates qua philosopher's counterparts are philosophers. Similarly, Socrates qua Greek is the truthmaker for $<$ Socrates is Greek>. But our views are importantly different (though similarly motivated). For one thing, Lewis's account requires the acceptance of his own counterpart theory and its commitment to possibilia, whereas my view has no need of it, once modal anti-realism is on board. Furthermore, Lewis maintains that Socrates qua philosopher just is Socrates qua Greek, although they have different (modal) properties. (Moreover, Socrates himself is identical to any Socrates qua what-have-you.) Here we have a violation of Leibniz's Law. It's also unclear just who Socrates is such that he can be considered now under one counterpart relation, now under another.

My view not only is distinct from Lewis's, but also boasts a number of advantages. For the modal skeptic, what 'Socrates' refers to is a function of what features are tied up in its use. We need essential features to succeed in referring to anything with 'Socrates'; the presupposed essential features are what allow us to engage in modal thinking about Socrates, and to

\footnotetext{
${ }_{11}$ An important question here is whether Philocrates meets the other conditions, beyond bare necessitation, that are necessary for making true $<$ Socrates is a philosopher $>$. Just what those conditions are is contentious (see note 2), but it's generally agreed that either truths are in some sense about their truthmakers (Merricks 2007), or that truthmakers are relevant to their corresponding truths (Restall 1996). While the matter deserves more careful inspection, it's prima facie plausible that the challenge can be met, given the very intimate connection between Socrates and Philocrates, and so a very intimate connection between Philocrates and truths about Socrates.
} 
contemplate him in counterfactual scenarios. Simply put, to speak of Socrates independently of any modal profile is to speak nonsense. Plus, on my view, Philocrates is not identical to Socrates (and so Philocrates is not Lewis's Socrates qua philosopher), for they have different properties, and so Leibniz's Law is maintained. Again, my view requires a commitment to a particular kind of plenitude, though this will not be seen as any sort of cost by the thoroughgoing modal skeptic; just as the Humean sees no vicious ontological proliferation behind mereological universalism, the modal skeptic sees no vicious ontological proliferation behind modal plenitude. Furthermore, it maintains that Socrates really is essentially human; to talk about something with a different modal profile is indeed to talk about something else.

\section{Conclusion}

There is obviously much more to be said in defense of modal skepticism, parity, and plenitude, and more details to flesh out concerning truthmaker theory paired with modal skepticism. My attention has been focused squarely on the necessitation condition of the truthmaking relation, and on truthmakers for contingent predications. The scope of truthmaker theory is far wider, and my remarks for now must remain programmatic. What I hope to have accomplished is a demonstration that truthmaker theory can survive the abandonment of its dogma about realist de re modality and essences. That doctrine is problematic on its own, and truthmaker theory is more metaphysically acceptable without it. Ditching the dogma yields further fruits as well, paving the way for an austere, nominalistically-friendly ontology that nevertheless provides truthmakers for contingent predications.

\section{Acknowledgments}

This paper was presented at the Northern Institute of Philosophy's Early Career Conference in June 2013, at the University of Aberdeen. My thanks go to the conference organizers for putting on an excellent event, and to all the conference participants for their helpful questions and comments. Thanks also go to the excellent referees for Thought. Special thanks go to Carrie Ichikawa Jenkins for her comments during the conference and after, and to Sam Baron for his extensive feedback on the paper. An early version of this paper was presented to the Department of Philosophy at the National University of Singapore in February 2013; I thank the audience there for a lively and productive session. 
References

Armstrong, D. M. 2004. Truth and Truthmakers. Cambridge: Cambridge University Press.

Asay, Jamin. 2012. A truthmaking account of realism and anti-realism. Pacific Philosophical Quarterly 93: 373-394.

Beebee, Helen, and Julian Dodd. 2005. Introduction. In their Truthmakers: The Contemporary Debate, 1-16. Oxford: Clarendon Press.

Bennett, Karen. 2004. Spatio-temporal coincidence and the grounding problem. Philosophical Studies 118: 339-371.

Blackburn, Simon. 1986. Morals and modals. In Fact, Science and Morality: Essays on A J. Ayer's Language, Truth and Logic, eds. Graham Macdonald and Crispin Wright, 119-141. Oxford: Basil Blackwell.

Cameron, Ross Paul. 2008a. How to be a truthmaker maximalist. Noûs 42: 410-421.

—. 2008b. Truthmakers and modality. Synthese 164: 261-280.

—. 2008c. Truthmakers, realism and ontology. Philosophy 83: 107-128

Dodd, Julian. 2002. Is truth supervenient on being? Proceedings of the Aristotelian Society (New Series) 102: 69-85.

Field, Hartry. 1980. Science Without Numbers. Princeton: Princeton University Press.

Fine, Kit. 1994. Essence and modality. Philosophical Perspectives 8: 1-16.

Fox, John F. 1987. Truthmaker. Australasian Journal of Philosophy 65: 188-207.

Goff, Philip. 2010. Orthodox truthmaker theory cannot be defended by cost/benefit analysis. Analysis 70: 45-50.

Hawthorne, John. 2006. Metaphysical Essays. Oxford: Clarendon Press.

Kripke, Saul A. 1972. Naming and necessity. In Semantics of Natural Language, eds. Donald Davidson and Gilbert Harman, 253-355. Dordrecht: D. Reidel Publishing Company.

Lewis, David. 2001. Truthmaking and difference-making. Noûs 35: 602-615.

—. 2003. Things qua truthmakers. In Real Metaphysics: Essays in Honour of D. H. Mellor, eds. Hallvard Lillehammer and Gonzalo Rodriguez-Pereyra, 25-42. London: Routledge.

Lowe, E. J. 2007. Truthmaking as essential dependence. In Metaphysics and Truthmakers, ed. JeanMaurice Monnoyer, 237-259. Frankfurt: Ontos Verlag.

Mackie, J. L. 1977. Ethics: Inventing Right and Wrong. London: Penguin Books.

Merricks, Trenton. 2007. Truth and Ontology. Oxford: Clarendon Press.

Parsons, Josh. 2005. Truthmakers, the past, and the future. In Truthmakers: The Contemporary Debate, eds. Helen Beebee and Julian Dodd, 161-174. Oxford: Clarendon Press. 
Putnam, Hilary. 1975. The meaning of "meaning". Minnesota Studies in the Pbilosophy of Science 7: 131-193.

Quine, Willard Van Orman. 1961. Reference and modality. In his From a Logical Point of View: 9 Logico-Philosophical Essays, Second, revised edition, 139-159. Cambridge: Harvard University Press.

- 1966. Three grades of modal involvement. In his The Ways of Paradox and Other Essays, 156174. New York: Random House.

Restall, Greg. 1996. Truthmakers, entailment and necessity. Australasian Journal of Philosophy 74: 331-340.

Rodriguez-Pereyra, Gonzalo. 2005. Why truthmakers. In Truthmakers: The Contemporary Debate, eds. Helen Beebee and Julian Dodd, 17-31. Oxford: Clarendon Press.

—. 2006. Truthmakers. Philosophy Compass 1: 186-200.

Salmon, Nathan. 2005. Reference and Essence. Second edition. Amherst, NY: Prometheus Books.

Sanson, David, and Ben Caplan. 2010. The way things were. Philosophy and Phenomenological Research 81: 24-39.

Schaffer, Jonathan. 2008. Truthmaker commitments. Philosophical Studies 141: 7-19

Sidelle, Alan. 1989. Necessity, Essence, and Individuation: A Defense of Conventionalism. Ithaca: Cornell University Press.

—. 2009. Conventionalism and the contingency of conventions. Nô̂s 43: 224-241. 